\title{
KARAKTERISTIK SUHU, SALINITAS DAN KLOROFIL-A DI PULAU SIMEULUE PROVINSI ACEH UNTUK MENGESTIMASI ZONASI IKAN
}

\author{
Characteristics of Temperature, Salinity and Chlorophyll-a on Simeulue island, Aceh \\ Province to Estimate Coral Fish Zoning
}

\author{
Edwarsyah $^{\text {a,*}}{ }^{\text {, Nazli Raudhati }}{ }^{\mathrm{a}}$,Djumanto $^{\mathrm{b}}$, Afrizal Hendric ${ }^{\mathrm{c}}$, Nabil Zurba ${ }^{\mathrm{a}}$, Burhanis ${ }^{\mathrm{d}}$ \\ aProgram Studi Sumber Daya Akuatik, Fakultas Perikanan dan Ilmu Kelautan, \\ Universitas Teuku, Aceh Barat, 23681, Indonesia \\ bLaboratory of Aquatic Resource Management Department of Fisheries, Faculty of Aquaculture, \\ Gadjah Mada University, Yogyakarta, 55281, Indonesia \\ 'Program Studi Akuakultur, Fakultas Perikanan dan Ilmu Kelautan, Universitas Teuku, \\ Aceh Barat, 23681, Indonesia

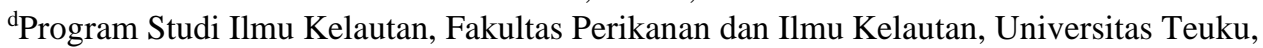 \\ Aceh Barat, 23681, Indonesia
}

*Koresponden penulis : edwarsyah@utu.ac.id

\begin{abstract}
Abstrak
Tujuan penelitian ini untuk mengetahui karakteristik sebaran suhu perairan laut, salinitas, klorofil- $a$ dan mengestimasi keberadaan ikan karang pada bulan Februari-Maret 2020 di perairan Pulau Simeulue Provinsi Aceh. Metode yang digunakan dalam penelitian ini adalah metode kualitatif dan kuantitatif. Data suhu, salinitas dan klorofil diolah menggunakan software Ocean Data View versi 4.4 (ODV), Pembuatan peta menggunakan Software ArcGis versi 10.2. Suhu perairan laut Pulau Simeulue pada Tahun 2017 relatif tertinggi dengan nilai suhu $27.5-34^{\circ} \mathrm{C}$ dan terendah dengan nilai suhu $26-3^{\circ} \mathrm{C}$. Salinitas permukaan laut Pulau Simeulue pada tahun 2017 tertinggi terjadi pada bulan Desember dengan nilai 31-36 psu, terendah terjadi pada bulan Januari dengan nilai 30-35.50 psu. Sebaran klorofil-a pada tahun 2017 Pulau Simeulue adalah $0-2.25 \mathrm{mg} / \mathrm{m}^{3}$. Nilai sebaran klorofil-a tertinggi terjadi pada bulan Januari yaitu $0-2.25 \mathrm{mg} / \mathrm{m}^{3}$ dan terendah terjadi pada bulan November yaitu $0-0.4 \mathrm{mg} / \mathrm{m}^{3}$. Sebaran Paracanthurus hepatusdi Pulau Simeulue diestimasi terdapat pada suhu maksimum $34.5^{\circ} \mathrm{C}$ dan suhu minimum $28.50^{\circ} \mathrm{C}$. Sebaran Amphirion polymnus di Pulau Simeulue diduga terdapat pada suhu maksimum $34.61^{\circ} \mathrm{C}$ dan minimum $27^{\circ} \mathrm{C}$. Sebaran Lutjanus argentimaculatu di Pulau Simeulue diduga terdapat pada suhu maksimum $35.61^{\circ} \mathrm{C}$ dan minimum $21.42^{\circ} \mathrm{C}$. Sebaran Epinephelus fuscoguttatus di Pulau Simeulue diduga terdapat pada suhu maksimum $34.61^{\circ} \mathrm{C}$ dan suhu minimum $28^{\circ} \mathrm{C}$.
\end{abstract}

Kata kunci: Ikan Karang, Klorofil-a, Pulau Simeulue, Salinitas, Suhu Perairan Laut

\begin{abstract}
This study is aimed to analyse the characteristics of the distribution of sea water temperature, salinity, chlorophyll-a and estimate the presence of coral fish in February-March 2020 in the waters of Simeulue Island of Aceh Province. The methods used in this research are qualitative and quantitative methods. Temperature, salinity, and chlorophyll data are processed using Ocean Data View version 4.4 (ODV) software, map creation using ArcGis Software version 10.2. Simeulue Island's sea water temperature in 2017 was relatively high with a temperature value of $27.5-34{ }^{\circ} \mathrm{C}$ and low with a temperature value of $26-3{ }^{\circ} \mathrm{C}$. Simeulue Island Sea level salinity in 2017 was relatively high in December with a value of 31-36 psu, the lowest occurred in January with a value of 30-35.50 psu. The distribution of chlorophyll-a in 2017 Simeulue Island was $0-2.25 \mathrm{mg} / \mathrm{m}^{3}$. The lowest chlorophyll-a distribution value occurred in November at $0-0.4 \mathrm{mg} / \mathrm{m}^{3}$, the highest occurred in January at 0-2.25 $\mathrm{mg} / \mathrm{m}^{3}$. The distribution of Paracanthurus hepatus on Simeulue Island is thought to exist at a minimum temperature of $28.50^{\circ} \mathrm{C}$ and a maximum temperature of $34.5^{\circ} \mathrm{C}$. The spread of Amphirion polymnus on Simeulue Island is thought to be at a minimum temperature of $27^{\circ} \mathrm{C}$ and a maximum of $34.61^{\circ} \mathrm{C}$. The spread of Lutjanus argentimaculatu on Simeulue Island is thought to exist at a minimunm temperature of $21.42^{\circ} \mathrm{C}$ and a maximum temperature of $35.61{ }^{\circ} \mathrm{C}$. The distribution of Epinephelus fuscoguttatus on Simeulue Island is thought to be at a minimum temperature of $28^{\circ} \mathrm{C}$ and a maximum temperature of $34.61^{\circ} \mathrm{C}$.
\end{abstract}

Keywords: Coral Fish, Chlorophyll-a, Simeulue Island, Salinity, Sea Water Temperature 


\section{PENDAHULUAN}

Indonesia merupakan negara kepulauan terbesar di dunia yang memiliki 13.466 pulau yang tersebar dari Sabang hingga Merauke[1] Dengan panjang garis pantai mencapai 99.093 $\mathrm{Km}$ dan luas wilayah perairan 6.3 juta $\mathrm{Km} 2$ [1]. Sementara, terumbu karang Indonesia merupakan pusat dari segitiga terumbu karang dunia atau Center of coral triangle[2].Sekitar $71 \%$ seluruh genus karang yang ada di dunia dapat ditemukan di Indonesia[3], 2005).Selain itu, sekitar $51 \%$ terumbu karang di Asia Tenggara, dan $18 \%$ terumbu karang di dunia berada di wilayah perairan Indonesia[4]. Kekayaan laut Indonesia memberikan manfaat ekonomi dan sosial untuk penduduk Indonesia, terutama 60 juta masyarakat yang tinggal di daerah pesisir[4], melalui perikanan, pariwisata, pertambangan dan transportasi.

Pulau Simeulue, Provinsi Aceh merupakan salah satu pulau yang terletak di Samudera Hindia dan terpisah $150 \mathrm{~km}$ dari daratan pulau Sumatera. Pulau Simeulue kaya akan sumberdaya perairan dan pesisir yang diantaranya pantai yang indah,mangrov yang luas, ikan karang yang melimpah, perairan yang bersih, dan jernih serta biota laut lainnya seperti rumput laut,kepiting, tripang serta lobster yang menjadi ikon dari pulau ini. Meskipun kaya akan sumberdaya perairan, masyarakat Pulau Simeulue lebih dominan memanfaatkan lahan pertanian daripada perikanan. Memiliki potensi perikanan yang cukup besar dibandingkan daerah lainnya masyarakat pulau Simeulue belum dapat mengelola dan memanfaatkan sumberdaya perikanan secara optimal. Pengelolaan Sumberdaya perikanan tidak lepas dengan wilayah laut, pesisir dan ekosistem yang terdapat di dalamnya.
Pengelolaan sumberdaya perikanan yang tidak memadai mengakibatkan banyak timbul masalah dalam pengembangan sektor ini. Sektor perikanan merupakan sektor terpenting yang harus dikelola dan dilestarikan untuk keberlanjutan sumberdaya perikanan bagi masyarakat Indonesia terkhusus Pulau Simeulue yang secara geografis dikelilingi oleh lautan yang sebagian besar masyarakat bermata pencaharian sebagai nelayan. Sehingga penelitian ini sangat penting dilakukan penelitian tentang Estimasi Zonasi Ikan Karang Berdasarkan Karakteristik Suhu, Salinitas dan Klorofil-a di Pulau Simeulue Provinsi Aceh. Oleh karena itu, riset ini bertujuan untuk mengetahui karakteristik sebaran suhu perairan laut (vertical dan horizontal), salinitas (vertical dan horizontal), dan klorofil-a (horizontal) di perairan Pulau Simeulue, serta mengestimasi keberadaan ikan karang (Paracanthurus hepatus, Amphiprion polymnus, Lutjanus argentimaculatus dan Epinephelus fuscoguttatus) di perairan Pulau Simeulue Provinsi Aceh berdasarkan suhu permukaan laut.

\section{METODE PENELITIAN}

Adapun penelitian ini dilakukan pada bulan Februari-Maret 2020 di Perairan Pulau Simeulue Provinsi Aceh. sedangkan untuk pengolahan dan analisis data, pola sebaran suhu, salinitas, klorofil-a pada lapisan permukaan laut dan pembuatan peta pada Pusat Riset Kelautan, Badan Riset Sumber Daya Manusia Kelautan dan Perikanan, Kementerian Kelautan dan Perikanan, Jakarta Utara.

\section{Alat dan Bahan \\ Adalah alat dan bahan yang digunakan selama berlangsung penelitian ini sesuai dengan fungsi dapat dilihat pada Tabel 1}


Tabel 1. Alat dan Bahan yang digunakan selama penelitian.

\begin{tabular}{|c|c|c|}
\hline No & Alat dan Bahan & Fungsi \\
\hline 1 & $\begin{array}{l}\text { Software Ocean Data View (ODV) } \\
\text { Versi } 4.4\end{array}$ & $\begin{array}{l}\text { Mengolah data pola sebaran suhu, salinitas dan klorofil-a pada } \\
\text { lapisan permukaan laut }\end{array}$ \\
\hline 2 & Software ArcGIS versi 10.2 & Pembuatan peta \\
\hline 3 & Software Ms.Word & Penulisan analisis data dalam bentuk tulisan \\
\hline 4 & Software Ms. Excel & Mengolah Data pola sebaran suhu, salinitas dan klorofil \\
\hline 5 & Laptop Deel Inspiron 143000 & $\begin{array}{l}\text { Alat untuk mengoperasikan software Browser, Ms. Word, } \\
\text { ODV dan ArcGIS } 10.2\end{array}$ \\
\hline 6 & Data suhu dan Salinitas & Bahan dalam pengolahan data suhu dan salinitas secara spasial \\
\hline 7 & Data Klorofil & Bahan dalam pengolahan data klorofil secara spasial \\
\hline
\end{tabular}

\section{Metode}

Metode yang digunakan dalam penelitian ini adalah metode kualitatif dan kuantitatif[5] mendefinisikan metode penelitian kualitatif sebagai "jenis penelitian yang temuantemuannya tidak diperoleh melalui prosedur statistik atau bentuk hitungan lainnya[5] menyatakan bahwa penelitian kualitatif adalah penelitian yang bermaksud untuk memahami fenomena tentang apa persepsi, motivasi, tindakan dan lain lain, secara holistic dan dengan cara deskripsi dalam bentuk kata-kata dan bahasa, pada suatu konteks khusus yang lamiah dan dengan memanfaatkan berbagai metode alamiah. Dengan demikian metode kualitatif lebih mengutamakan kemampuan peneliti untuk mendalami focus permasalahan yang di teliti. Menurut Subana dan Sudrajat (2005: 25) penelitian kuantitatif dilihat dari segi tujuan, penelitian ini dipakai untuk menguji suatu teori, menyajikan suatu fakta atau mendeskripsikan statistik, dan untuk menunjukkan hubungan antar variabel dan adapula yang sifatnya mengembangkan konsep, mengembangkan pemahaman atau mendiskripsikan banyak hal.

\section{Pengumpulan Data}

Data yang digunakan pada penelitian ini adalah data sekunder. Menurut[6] menjelaskan data sekunder adalah data yang mengacu pada informasi yang dikumpulkan dari sumber yang telah ada.Sumber data sekunder adalah catatan atau dokumentasi perusahaan, publikasi pemerintah, analisis industri oleh media, situs Web, internet dan seterusnya. Selanjutnya diperjelas oleh[7] Data sekunder adalah sumber data yang tidak langsung memberikan data kepada pengumpul data.Data sekunder pada penelitian ini berupa studi literatur dan data satelit yang diperoleh dari Hycom dan Erddap kemudian diolah menggunakan software ODV.

Variable yang digunakan dalam penelitian ini adalah persebaran Suhu, Salinitas, Kedalaman dan Klorofil-a.Langkah penelitian yang dilakukan adalah melakukan pengunduhan data menggunakan ODV, yang dilanjutkan dengan pengolahan menggunakan ms.excel, hasil ms.excel divisualisasikan menggunakan ODV.

\section{HASIL DAN PEMBAHASAN}

\section{Gambaran Umum Pulau Simeulue}

Pulau Simeulue secara geografis berada pada koordinat $02^{\circ} 15^{\prime} 03^{\prime \prime}-02^{\circ} 55^{\prime} 04^{\prime \prime}$ Lintang Utara dan $95^{\circ} 40^{\prime} 15^{\prime}$ ' - 96 $36^{\circ} 30^{\prime} 45^{\prime}$, Bujur Timur. Pulau Simeulue termasuk ke dalam zona iklim tropika basah dengan temperatur udara berkisar antara $23^{\circ}-34,5^{\circ} \mathrm{C}$ dan rata-rata harian antara $25^{\circ}-27^{\circ} \mathrm{C}$. Musim hujan umumnya terjadi antara bulan September-Februari, sedangkan musim kemarau pada umumnya antara bulan Maret-Agustus. Curah hujan terendah terjadi pada bulan Juni, sedangkan curah hujan tertinggi terjadi pada bulan Maret. Berdasarkan pada tipe iklim Oldeman, Pulau Simeulue memiliki tipe iklim A yaitu daerah dengan bulan basah selama 9 bulan berturut-turut dan selama dua bulan atau kurang mengalami musim kering. Bulan 
basah adalah curah hujan lebih dari 200 mm.bulan[7].

Keadaan cuaca di Kabupaten Simeulue ditentukan oleh penyebaran musim, dimana musim Barat berlangsung sejak Bulan September sampai dengan Bulan Februari, ditandai dengan terjadinya musim badai dan gelombang besar yang berasal dari Lautan Hindia sehingga sangat berbahaya bagi pelayaran. Sedangkan pada musim Timur berlangsung sejak Bulan Maret sampai dengan Bulan Agustus ditandai dengan musim kemarau diselingi oleh hujan yang tidak merata dan keadaan laut sedikit tenang[8].

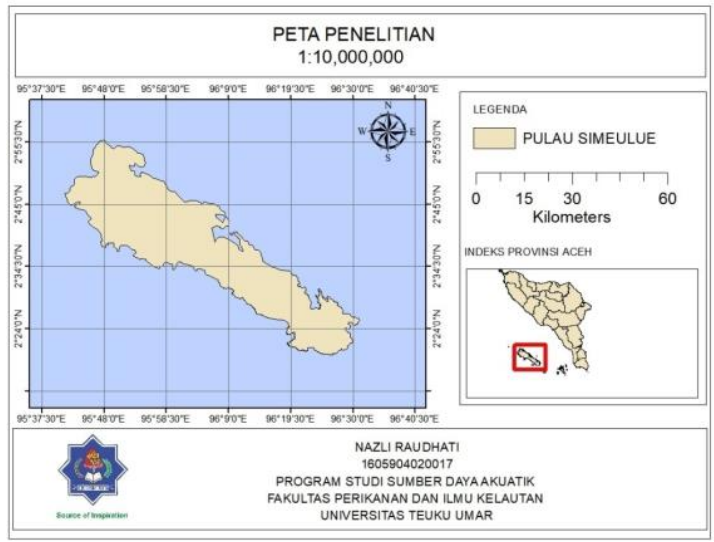

Gambar 1. Peta Pulau Simeulue

\section{Sebaran Suhu Perairan Laut di Pulau Simeulue Tahun 2017}

Suhu perairan laut Pulau Simeulue pada tahun 2017 tertinggi terjadi pada bulan Juli lebih tepat musim timur dengan nilai suhu 27.5-34 ${ }^{\circ} \mathrm{C}$. Pada musim timur kenaikan suhu disebabkan adanya penyinaran matahari yang tinggi dan terus menerus sehingga membawa massa air bersuhu tinggi.

Suhu perairan laut Pulau Simeulue pada tahun 2017 terendah terjadi pada bulan Desember dan bulan Januari lebih tepat terjadi pada musim barat dengan nilai suhu $26-31^{\circ} \mathrm{C}$. Pada musim barat suhu relatif rendah, [8] menjelaskan bahwa hal ini dikarenakan mendapat masukkan massa air dingin yang berasal dari benua Asia menuju Australia dan melewati perairan barat Sumatera.

Pada lapisan dalam suhu air laut cenderung lebih rendah disebabkan oleh kurangnya penyinaran matahari. Semakin dalam suatu perairan laut maka suhu akan semakin rendah. Hal ini sesuai dengan penelitian[8] "Pada lapisan dalam suhu air laut cenderung rendah, hal ini tidak ada penyinaran matahari dan kecapatan angin yang mempengaruhi pergerakan suhu air laut dari tempat ke tempat yang lainnya".

Tabel 2. Sebaran Suhu Perairan Laut (0-150m) Pulau Simeulue Tahun 2017.

\begin{tabular}{llll}
\hline Bulan & $\begin{array}{l}\text { Kedalaman } 0 \mathrm{~m} \\
\left({ }^{\circ} \mathrm{C}\right)\end{array}$ & $\begin{array}{l}\text { Kedalaman } 75 \mathrm{~m} \\
\left({ }^{\circ} \mathrm{C}\right)\end{array}$ & $\begin{array}{l}\text { Kedalaman } 150 \mathrm{~m} \\
\left({ }^{\circ} \mathrm{C}\right)\end{array}$ \\
\hline Januari & $26-31$ & $19-31$ & $12-23$ \\
Februari & $26-31.50$ & $19-31$ & $12-20$ \\
Maret & $26-33.50$ & $19-30$ & $13-21$ \\
April & $27-33$ & $21-30$ & $13-23$ \\
Mei & $27-33.50$ & $23-30$ & $13-23$ \\
Juni & $27.50-34$ & $20-30$ & $13-24$ \\
Juli & $27.50-33.50$ & $19-31$ & $12-23$ \\
Agustus & $26-32$ & $20-31$ & $12-21$ \\
September & $26.5-31.50$ & $17-30$ & $11-22$ \\
Oktober & $26-32$ & $18-31$ & $13-22$ \\
November & $26.50-31.50$ & $19-31$ & $12.5-27.50$ \\
Desember & $26-31$ & $18-30$ &
\end{tabular}



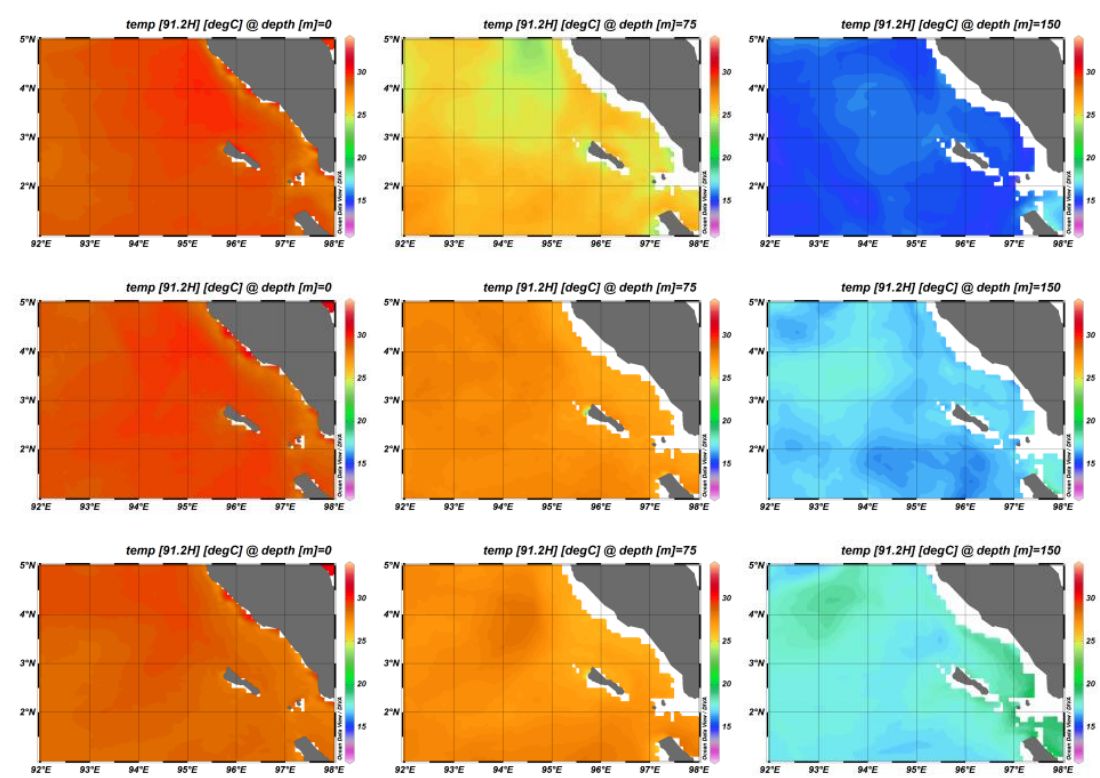

Gambar 2. Sebaran Suhu Perairan Laut (0-150m) Pulau Simeulue Tahun 2017

\section{Sebaran Salinitas Permukaan Laut Pulau Simeulue Tahun 2017}

Salinitas permukaan laut Pulau Simeulue pada tahun 2017 tertinggi terjadi pada bulan Desember dengan nilai 31-36 psu. Salinitas terendah terjadi pada bulan Januari dengan nilai 30-35.50 psu. Semakin dalam kedalaman laut nilai salinitas lebih tinggi sebagaimana dijelaskan oleh[8] bahwa pada lapisan permukaan salinitas umumnya lebih rendah daripada lapisan dalam. Tingginya salinitas juga dipengaruhi oleh tingginya temperatur karena adanya penguapan. [8]menjelaskan bahwa meningkatnya salinitas dipengaruhi oleh penguapan, curah hujan dan banyak sedikit sungai yang bermuara di perairan barat sumatera.

Tabel 3. Sebaran Salinitas di parairan laut (0-150m) Pulau SimeulueTahun 2017.

\begin{tabular}{llll}
\hline Bulan & $\begin{array}{l}\text { Kedalaman } \mathbf{0 m} \\
(\boldsymbol{p} \boldsymbol{s} \boldsymbol{u})\end{array}$ & $\begin{array}{l}\text { Kedalaman } \\
(\boldsymbol{p} \boldsymbol{s} \boldsymbol{u})\end{array}$ & $\begin{array}{l}\text { Kedalaman } \mathbf{1 5 0 m} \\
(\boldsymbol{p} \boldsymbol{s} \boldsymbol{u})\end{array}$ \\
\hline Januari & $30-35.5$ & $31-37$ & $33.5-37.5$ \\
Februari & $30-35.5$ & $33-37$ & $34.25-36.5$ \\
Maret & $30.5-35.5$ & $33-37$ & $34.25-36.75$ \\
April & $31-35.5$ & $32-36.5$ & $34.25-36.75$ \\
Mei & $31-35$ & $33.75-36$ & $34-37$ \\
Juni & $31-35$ & $33.75-36$ & $34-36.5$ \\
Juli & $31-35$ & $32.5-36.5$ & $34-37$ \\
Agustus & $31.5-35$ & $32.5-37.5$ & $34-36.75$ \\
September & $31.5-35$ & $33-37$ & $34-36.5$ \\
Oktober & $31.25-34.5$ & $32-36$ & $33.75-37.25$ \\
November & $31-35$ & $33.25-36.5$ & $34-36.5$ \\
Desember & $31-36$ & $33-36$ & $34-37$ \\
\hline
\end{tabular}



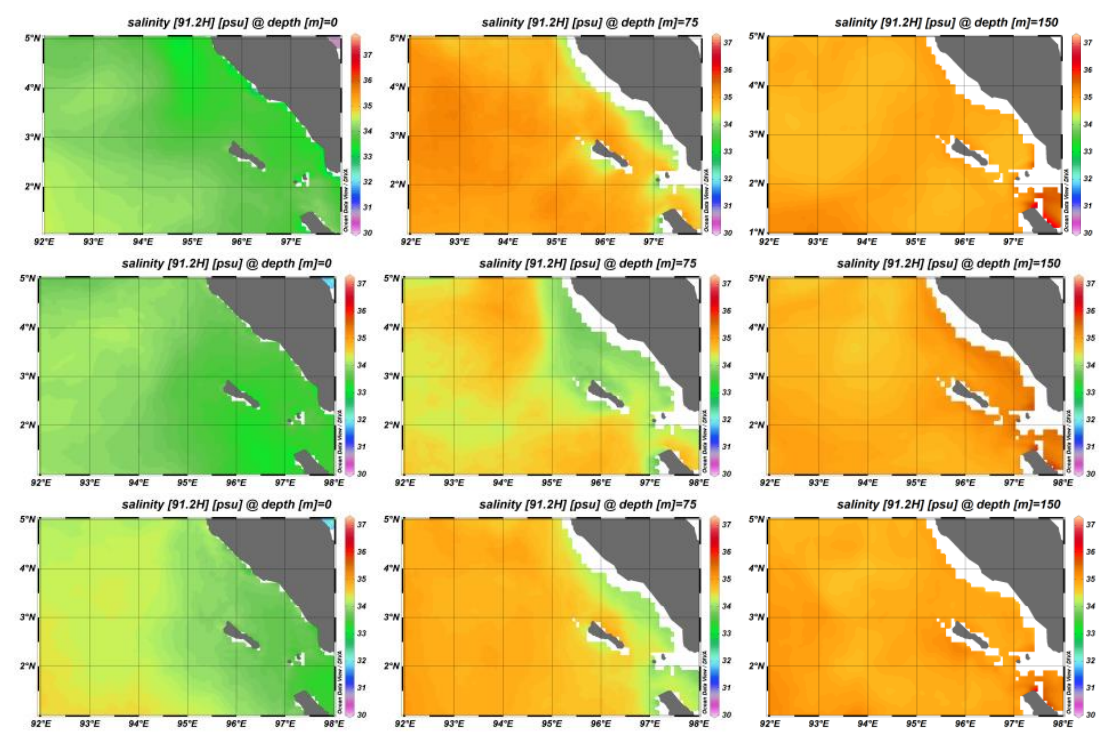

Gambar 3. Sebaran Salinitas di Perairan (0-150m) Pulau Simeulue Tahun 2017

\section{Sebaran Klorofil-a Permukaan Laut Pulau Simeulue Tahun 2017}

Sebaran klorofil-a pada tahun 2017 Pulau Simeulue adalah $0-2.25 \mathrm{mg} / \mathrm{m}^{3}$. Sebaran klorofil-a terendah terlihat pada bulan November yaitu $0-0.4 \mathrm{mg} / \mathrm{m}^{3}$. Sebaran klorofila tertinggi terlihat pada bulan Januari yaitu 0 $2.25 \mathrm{mg} / \mathrm{m}^{3}$.Konsentrasi klorofil-a yang tinggi berada di perairan yang lebih dekat dengan daratan. Konsentrasi klorofil-a pada bagian selatan laut Pulau Simeulue cenderung lebih tinggi daripada bagian utara laut Pulau Simeulue. Hal ini disebabkan oleh bagian selatan Pulau Simeulue merupakan bagian yang berbatasan langsung dengan Samudera Hindia yang memiliki transport nutrien dari daratan melalui sungai. Masukan air dengan nutrien yang tinggi menyebabkan terjadinya Upwelling. hal tersebut sesuai dengan pernyataan[9] yang menyatakan bahwa proses upwelling ini mengakibatkan kadar nutrien di permukaan perairan tinggi yang memicu pesatnya perkembangan fitoplankton sehingga konsentrasi klorofil-a menjadi lebih tinggi dan nilai suhu permukaan laut menjadi lebih rendah dibanding daerah sekitarnya. Pada bulan januari tahun 2017 suhu permukaan laut merupakan suhu terendah sepanjang tahun 2017 dengan nilai suhu $26-31^{\circ} \mathrm{C}$.

Penurunan sebaran klorofil-a pada bulan November terjadi karena peningkatan suhu perairan laut dimana semakin tinggi suhu perairan laut maka konsentrasi klorofil-a akan menurun sebagaimana dijelaskan oleh[7] Konsentrasi klorofil-a memiliki pola berkebalikan dengan suhu muka laut, dimana suhu muka laut rendah, konsentrasi klorofil-a semakin besar begitu juga sebaliknya. 
Tabel 4. Sebaran Klorofil-a Pulau Simeulue Tahun 2017.

\begin{tabular}{ll}
\hline Bulan & Nilai $\left(\mathbf{m g} / \mathbf{m}^{\mathbf{3}}\right)$ \\
\hline Januari & $0-2.25$ \\
Februari & $0.1-0.55$ \\
Maret & $0.1-0.55$ \\
April & $0.1-0.6$ \\
Mei & $0-1.1$ \\
Juni & $0.05-0.6$ \\
Juli & $0.05-0.65$ \\
Agustus & $0.1-0.65$ \\
September & $0-1.1$ \\
Oktober & $0.1-0.42$ \\
November & $0-0.4$ \\
Desember & $0.1-1.4$ \\
\hline
\end{tabular}
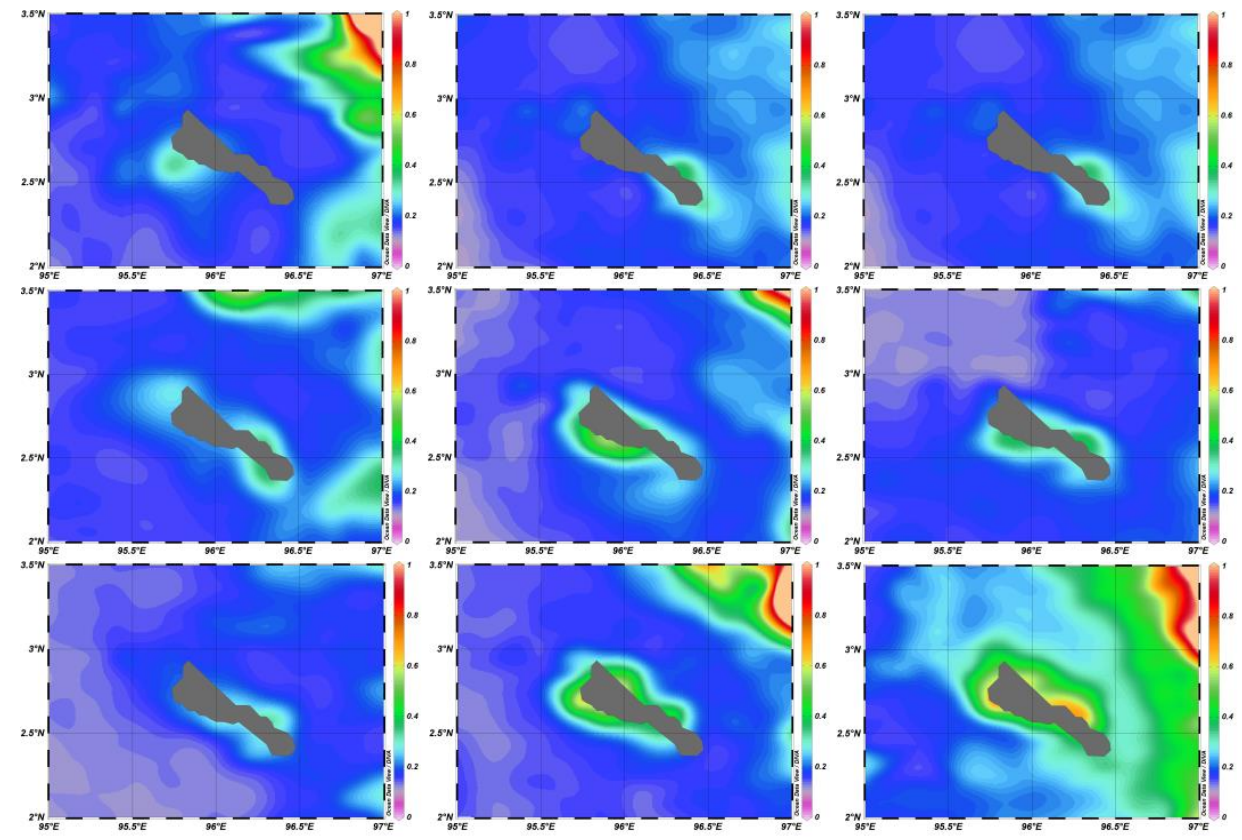

Gambar 4. Sebaran klorofil-a Permukaan Laut Pulau Simeulue Tahun 2017

\section{Estimasi Keberadaan Ikan Karang di Pulau Simeulue Paracanthurus hepatus}

Estimasi keberadaan Paracanthurus hepatus Tahun 2017 pada kedalaman 2 meter diduga terdapat pada nilai suhu $28.5^{\circ} \mathrm{C}, \quad 29.5^{\circ} \mathrm{C}, \quad 33.45^{\circ} \mathrm{C}, \quad 33.5$ dan $34^{\circ} \mathrm{C}$. Kedalaman 10 meter Paracanthurus hepatus diduga terdapat pada nilai suhu $28.5^{\circ} \mathrm{C}, 29^{\circ} \mathrm{C}, 29.9^{\circ} \mathrm{C}$, $30^{\circ} \mathrm{C}, \quad 33.45^{\circ} \mathrm{C}, \quad 33.5^{\circ} \mathrm{C}, \quad 34^{\circ} \mathrm{C}$ dan $34.5^{\circ} \mathrm{C}$. pada kedalaman $40 \mathrm{~m}$
sebaranParacanthurus hepatus diduga terdapat pada suhu $28^{\circ} \mathrm{C}, 28.5^{\circ} \mathrm{C}$, $28.9^{\circ} \mathrm{C}, 29^{\circ} \mathrm{C}, 29.5^{\circ} \mathrm{C}, 33.45^{\circ} \mathrm{C}, 33.5^{\circ} \mathrm{C}$, $34^{\circ} \mathrm{C}$ dan $34.5^{\circ} \mathrm{C}$. Berdasarkan hasil analisis data sebaranParacanthurus hepatus diduga terdapat pada suhu minimum dengan nilai $28.50^{\circ} \mathrm{C}$ dan suhu maksimum $34.50^{\circ} \mathrm{C}$. Setiawati et al., (2013) menyatakan bahwa Paracanthurus hepatus hidup berasosiasi dengan terumbu karang pada kedalaman $2 \mathrm{~m}-40 \mathrm{~m}$ dengan suhu di daerah tropis $24^{\circ} \mathrm{C}-26^{\circ} \mathrm{C}$. 
Tabel 5. Estimasi keberadaan Paracanthurus hepatus berdasarkan suhu di Perairan Laut Pulau Simeulue Pada Tahun 2017.

\begin{tabular}{|c|c|c|c|}
\hline Bulan & $\begin{array}{l}\text { Kedalaman } \\
2 \mathrm{~m}\left({ }^{\circ} \mathrm{C}\right)\end{array}$ & $\begin{array}{l}\text { Kedalaman } \\
\text { 10m }\left({ }^{\circ} \mathrm{C}\right)\end{array}$ & $\begin{array}{l}\text { Kedalaman } \\
40 \mathrm{~m}\left({ }^{\circ} \mathrm{C}\right)\end{array}$ \\
\hline Januari & $\begin{array}{l}28.5 \\
29.5 \\
34\end{array}$ & $\begin{array}{l}28.5 \\
29\end{array}$ & 34 \\
\hline Februari & $\begin{array}{l}28.5 \\
29\end{array}$ & $\begin{array}{l}28.9 \\
29 \\
29.5 \\
33.45 \\
33.5 \\
34\end{array}$ & $\begin{array}{l}28.5 \\
28.9 \\
29 \\
33.5 \\
34\end{array}$ \\
\hline Maret & $\begin{array}{l}28.9 \\
29.5 \\
34\end{array}$ & $\begin{array}{l}29.5 \\
30 \\
34\end{array}$ & $\begin{array}{l}29 \\
34 \\
34.5\end{array}$ \\
\hline April & 29.5 & $\begin{array}{l}29.5 \\
34 \\
34.5\end{array}$ & 28.9 \\
\hline Mei & - & - & $\begin{array}{l}28.9 \\
29 \\
34\end{array}$ \\
\hline Juni & $\begin{array}{l}29 \\
29.5 \\
34\end{array}$ & 34 & $\begin{array}{l}29 \\
34\end{array}$ \\
\hline Juli & $\begin{array}{l}28.9 \\
34\end{array}$ & $\begin{array}{l}29.5 \\
34\end{array}$ & $\begin{array}{l}28.9 \\
29 \\
29.5\end{array}$ \\
\hline Agustus & $\begin{array}{l}28.9 \\
29\end{array}$ & $\begin{array}{l}29 \\
33.5\end{array}$ & $\begin{array}{l}28 \\
29 \\
33.5\end{array}$ \\
\hline September & $\begin{array}{l}28.9 \\
29.5 \\
33.5\end{array}$ & $\begin{array}{l}28.5 \\
33.45 \\
34\end{array}$ & $\begin{array}{l}28.5 \\
34\end{array}$ \\
\hline Oktober & $\begin{array}{l}28.9 \\
34 \\
33.45\end{array}$ & 28.5 & $\begin{array}{l}28.9 \\
33.5\end{array}$ \\
\hline November & $\begin{array}{l}28 \\
28.5 \\
33 \\
33.45 \\
33.5\end{array}$ & $\begin{array}{l}28.5 \\
28.9 \\
33.5 \\
34\end{array}$ & $\begin{array}{l}28 \\
33.45 \\
34\end{array}$ \\
\hline Desember & $\begin{array}{l}28 \\
28.9 \\
34\end{array}$ & $\begin{array}{l}28 \\
33.5 \\
34 \\
\end{array}$ & 34.5 \\
\hline
\end{tabular}




\section{KESIMPULAN}

Berdasarkan pembahasan di atas kesimpulan dari penelitian ini adalah :

1. Suhu permukaan laut Pulau Simeulue pada Tahun 2017 relatif tinggi terjadi (musim timur) dengan nilai suhu 27.5$34^{\circ} \mathrm{C}$ dan relatif rendah terjadi pada bulan Desember dan bulan Januari (musim barat) dengan nilai suhu 26$3^{\circ} \mathrm{C}$.

2. Salinitas permukaan laut Pulau Simeulue pada tahun 2017 tertinggi tinggi terjadi pada bulan Desember dengan nilai 31-36 psu. Salinitas terendah terjadi pada bulan Januari dengan nilai 30-35.50 psu

3. Distribusi klorofil-a pada tahun 2017 Pulau Simeulue adalah $0-2.25 \mathrm{mg} / \mathrm{m}^{3}$. Nilai distribusi klorofil-a terendah terlihat pada bulan November yaitu $0-0.4 \mathrm{mg} / \mathrm{m}^{3}$. Nilai distribusi klorofil-a tertinggi terlihat pada bulan Januari yaitu $0-2.25 \mathrm{mg} / \mathrm{m}^{3}$.

4. Distribusi Paracanthurus hepatusdi Pulau Simeulue diduga terdapat pada suhu minimum $28.50^{\circ} \mathrm{C}$ dan suhu maksimum $34.5^{\circ} \mathrm{C}$.

5. Distribusi Amphirion polymnusdi Pulau Simeulue diduga terdapat pada suhu minimun $27^{\circ} \mathrm{C}$ dan maksimum $34.61^{\circ} \mathrm{C}$.

6. Distribusi

Lutjanus

argentimaculatusdi Pulau Simeulue diduga terdapat pada suhu minimunm $21.42^{\circ} \mathrm{C}$ dan suhu maksimun $35.61^{\circ} \mathrm{C}$.

7. Distribusi Epinephelus fuscoguttatusdi Pulau Simeulue diduga terdapat pada suhu minimum $28^{\circ} \mathrm{C}$ dan suhu maksimun $34.61{ }^{\circ} \mathrm{C}$.

\section{UCAPAN TERIMA KASIH}

Penulis mengucapkan terima kasih kepada Dr.-ing. Widodo S. Pranowo, M.Si selaku peneliti yang mendampingi selama penelitian dilaksanakan di Pusat Riset Kelautan, Badan
Riset dan Sumber Daya Manusia Kelautan dan Perikanan, Kementerian Kelautan dan Perikanan, Ancol Timur - Jakarta Utara.

\section{DAFTAR PUSTAKA}

[1] Estradivari, H. Christian, F. Fikri, Y. Muhammad, and S. Veda, "Kawasan Konservasi Perairan," WWF Jakarta Indones., 2017, [Online]. Available: http://awsassets.wwf.or.id/downloads/ mpa_for_fisheries_wwf_indonesia_20 17.pdf.

[2] M. S. Baskoro, "Pengembangan Perikanan Tangkap Berkelanjutan melalui Program pengayaan Stok Ikan," no. November, 2011.

[3] Q. Hasani, "Konservasi Sumberdaya Perikanan Berbasis Masyarakat, Implementasi Nilai Luhur Budaya Indonesia Dalam Pengelolaan Sumberdaya Alam," Aquasains, vol. 1, no. 1, pp. 35-44, 2012, [Online]. Available:

http://jurnal.fp.unila.ac.id/index.php/JP $\mathrm{BP} /$ article/view/18.

[4] L. Burke, E. Selig, and M. Spalding, Reefs at Risk in Southeast Asia. 2002.

[5] C. Cantú, R. G. Wright, J. M. Scott, and E. Strand, "Assessment of current and proposed nature reserves of Mexico based on their capacity to protect geophysical features and biodiversity," Biol. Conserv., vol. 115, no. 3, pp. 411417 , 2004, doi: 10.1016/S00063207(03)00158-7.

[6] A. Sutrisna, "( Epinephelus fuscoguttatus Forsskal , 1775 ) DI PERAIRAN PULAU PANGGANG , KEPULAUAN SERIBU," 2011.

[7] T. Herawati, W. Lili, R. Mustikawati, A. Adhardiansyah, and S. Y. Diliana, "Pertumbuhan Ikan Paray (Rasbora Argyrotaenia, Blkr) di Waduk Jatigede Kabupaten Sumedang Provinsi Jawa Barat," Akuatika Indones., vol. 2, no. 1, p. 71, 2017, doi: 10.24198/jaki.v2i1.23428.

[8] Y. Yonvitner, A. Muhtadi, and Edwarsyah, Pengantar Pengelolaan Perikanan Berbasis Ekologis /EAFM, 
no. December. 2018.

[9] L. Burke, K. Reytar, M. Spalding, and

A. Perry, Reefs at Risk Revisited, vol.

74, no. 3. 2011. 